from the mother of certain factors of activation of enzymatic systems [4, p. 2803], as well as epigenetic changes in the genome, such as methylation of DNA regions or acetylation of histone proteins at the embryonic stage of development [1, p. 900; 2, p. 10121].

\title{
References:
}

1. Alekseev V., Lampert W. Maternal control of resting-egg production in Daphnia. Nature. 2001. Vol. 414. P. 899-901.

2. Jeremias G., Barbosa J., Marques S.M. et al. Transgenerational inheritance of DNA hypomethylation in Daphnia magna in response to salinity stress. Environmental science \& technology. 2018. Vol. 52. Is. 17. P. 10114-10123.

3. Kirpenko N.I., Usenko O.M. Influence of higher aquatic plants on microalgae (a review). Hydrobiol. J. 2013. Vol. 49, No 2. P. 57-74.

4. Ortiz-Rodríguez R., Dao T.S., Wiegand C. Transgenerational effects of microcystin-LR on Daphnia magna. J. Exp. Biol. 2012. Vol. 215. P. 2795-2805.

5. Usenko O.M., Konovets I.N. Analysis of phenolcarbonic acids content in phytomass of higher aquatic plants. Hydrobiol. J. 2014. Vol. 50, No 5. P. 47-60.

6. Usenko O.M., Konovets I.N., Tarashchuk O.S., Gorbunova Z.N. Phenolcarbonic acids of the submerged aquatic plants and their effect on phytoepiphyton structure. Hydrobiol. J. 2019. Vol. 55, No 6. P. 55-64.

7. Usenko O.M., Sakevich O.Y., Balanda O.V. Resistance of algae to biologically active substances. Kyiv: Logos, 2010. 192 p. (in Ukrainian).

DOI https://doi.org/10.30525/978-9934-26-006-3-13

\section{ЕКОЛОГІЧНА ОЦІНКА ДЕНДРОФЛОРИ ПАРКОВОЇ ЕКОСИСТЕМИ «НАТАЛКА» В УМОВАХ УРБОСЕРЕДОВИЩА МІСТА КИЕВА}

\author{
Лавріненко В. М. \\ кандидат біологічних наук, \\ стариий викладач кафедри екологіі \\ Національний педагогічний університет імені М. П. Драгоманова \\ м. Київ, Украӥна
}

Вступ. Паркові екосистеми відіграють важливу роль в архітектурнопланувальній структурі міст. Вони використовуються при формуванні елементів забудови покращуючи середовище життя людей, сприяють 
урізноманітненню зовнішнього вигляду вулиць, створюють багатство кольорів і форм [5]. Ефективність функціонування паркової дендрофлори в урбоекосистемі залежить від багатьох факторів, зокрема від просторового типу зелених насаджень, адже великі зелені масиви ефективніше справляються із утворенням стабільного і комфортного мікроклімату в місті. Але в таких посадках втрачаються декоративні властивості рослин [7]. Під впливом комплексу несприятливих факторів міського середовища дендрофлора паркових екосистем характеризується рядом змін в зростанні і розвитку, відмиранням багаторічних пагонів, стає більш схильною до різних захворювань внаслідок зниження «імунітету». Це дає привід задуматися над ситуацією, що складається, в плані ступеня порушення урбофітоценозів i заходів щодо їх відновлення. Одним із шляхів іiї вирішення $\epsilon$ оптимізація внутрішньоміських деревних насаджень. Тож, питання, мінімізації антропогенного впливу та екологічної оцінки дендрофлори паркових екосистем міста, а саме дослідження стану дендрофлори парку «Наталка» в місті Києві на нині є актуальними.

Мета. Метою статті $є$ екологічна оцінка дендрофлори паркової екосистеми «Наталка» в умовах урбосередовища міста Києва.

Матеріал і методика дослідження. 3 метою оцінки дендрофлори паркової екосистеми «Наталка» в місті Києві здійснювались часті виїзди на територію парку в різні сезони. Під час дослідження застосовані методики: Алексєєва В.А. (1989) [2, с. 51-57.], Кофман Г. Б. (1986) [4]., Боголюбова А.С. (1996) [3], Агальцевої В. А. (2007) [1], Лук'янецької А.Г. (2010) [6,С. 21-25.], Поплавської Г.I. (1948) [8], П’ятницького С.С. (1960) [9], Циганова, 1976) [10].

Результати дослідження та їх обговорення.

«Наталка» - парк-урочище, яке розташоване вздовж берегової лінії Дніпра в місті Києві. До 2000-х років це була непримітна запущена зелена зона, яка підлягала забудові житловими будинками. На сьогодні парк знаходиться в однойменному урочищі в південній частині Оболонської набережної міста Києва. Поруч з ним, вздовж проспекту Героїв Сталінграду - розташовані житловий комплекс «Оазис» і третій мікрорайон Оболонського району. Офіційно парк «Наталка» був відкритий у 2017 році, на сьогоднішній день має площу 8 га.

Видовий склад дендрофлори парку «Наталка» утворюють 13 видів, які належать до 9 родин - Salicaceae, Betulaceae, Pinaceae, Oleaceae, Malvaceae, Fagaceae, Sapindaceae, Rosaceae, Ulmaceae. Найбільшу кількість видів має родина Вербові (Salicaceae), що складає 33\% від загальної кількості дерев у парку. Найчисленніший вид - осика (Populus tremula L.) - 20,1\%. Менш чисельними є види: в'яз шорсткий (Ulmus glabra Huds.) - 0,82\%, дуб звичайний (Quercus robur L.) 58 
$1,37 \%$, сосна звичайна (Pinus sylvestris L.) - 1,92\%, вишня дрібнопилчаста (Prunus serrulata L.) - 2,2\%. За ареалами поширення та умовами місцезростань види в парковій екосистемі $\epsilon$ : Північноамериканські, Свропейські, Західноазіатські.

Видовий склад дендрофлори парку в основному представлений едифікаторами та інтродуцентами. До видів едифікаторів дендрофлори паркової екосистеми належать - Populus tremula L., Betula pendula R., Tilia cordata M., Acer platanoides L., що в кількісному та видовому співвідношенні до всього деревостану складає 51,7 \%. До інтродукованих видів, що відіграють високу декоративну роль парку, належать: Prunus serrulata L., Fraxinus pennsylvanica M., та Populus trichocarpa Н., що відповідно складає 16,9 \% у кількісному та 31,4 \% у видовому співвідношенні.

Екологічне групування видів дендрофлори парку показало, що переважаючою групою - мезофіти (Betula pendula R., Quercus robur L., Populus trichocarpa H., Tilia cordata M., Prunus serrulata L., Ulmus glabra Н.), що складають $36 \%$ від загального числа екземплярів парку. Найменше представництво має група ксерофітів, яка представлена лише одним видом - Pinus sylvestris L. і складає всього 1,9\% від загальної чисельності. Варто відзначити, що значний відсоток (31,9\%) належить групам ксеромезофітів і мезогігрофітів. Групу ксеромезофітів утворюють види: Populus tremula L. та Picea glauca V., мезогігрофітів види - Fraxinus pennsylvanica M. та Acer platanoides L.

У парку «Наталка» $є$ представники досить світлолюбних видів, це зокрема: Betula pendula R., Pinus sylvestris L. та Salix alba L., дана група складає $27,8 \%$. Група власне світлолюбних видів $\epsilon$ найчисельнішою та має представництво 30,8\% (Populus tremula L., Populus nigra L., Populus trichocarpa Н.). Група видів геліосціофітів та сціогеліофітів (Quercus robur L., Picea glauca V., Fraxinus pennsylvanica M., Tilia cordata M., Acer platanoides L.) становить 41,3\%.

Найчисельнішою групою по відношенню до родючості грунту виявилися оліготрофи (60,8\%), до якої входять 7 видів із 13: Populus tremula L., Populus nigra var. Pyramidalis L., Salix alba L., Betula pendula R., Pinus sylvestris L., Picea glauca V., Ulmus glabra H. Найменше представництво має група мегатрофів $(15,9 \%)$, до якої входять 2 види: Acer platanoides L. та Quercus robur L.

Розподіл дендрофлори по відношенню до тепла показав, що більшість видів є морозостійкими - 64,4\%. До теплолюбних належить тільки єдиний екземпляр Populus nigra var. Pyramidalis L. - 0,27\%. Група середньовибагливих до температури становить 35,2\%, (Tilia cordata M., Quercus robur L., Acer platanoides L., Prunus serrulata L., Salix alba L., Ulmus glabra H.). 
Проводячи оцінку життєвого стану дендрофлори парку за шкалою Алєксєєва (1989), з'ясували, що деревостій характеризується як здоровий і належить до I категорії стану $(90,8 \%)$. Найвищий індекс життєвого стану має вид Populus tremula - $95 \%$, середні показники у виду Tilia cordata - 86,8\%, що в цілому є нормальним показником, оскільки липа відіграє роль активного буфера, тобто добре вбирає вуглекислий газ з повітря, концентрація якого в урбоекосистемах $\epsilon$ надлишковою.

Отримані дані свідчать про незначний негативний вплив антропогенних факторів, зокрема найнебезпечніший 3 них для дендрофлори - надлишковий вміст природних та шкідливих газів в повітрі, а також про відповідність екологічних умов до біологічних характеристик, тобто потреб зростаючих видів на території парку.

Провівши естетичну оцінку паркової системи та окремо представників дендрофлори (опираючись на методики Агальцевої В. А., Котелової Н. В.), з'ясували: більшість видів належать до 1 класу $(83,1 \%)$. Мають високі декоративні якості, $\epsilon$ основою пейзажної групи, і не потребують проведення заходів.

В фітоценозі паркової екосистеми «Наталка» практично відсутній підлісок, молоді екземпляри дерев знаходяться в окремих місцях і не мають подібності до природних фітоценозів (середньовікові формації берези повислої та низькорослі - до 2 м, посадки ялини канадської). Вертикальний розподіл визначений одним ярусом, оскільки дерев 2 ярусу небагато $\mathrm{i}$ вони переважно зростають відокремлено від основних масивів. Крони дерев (за шкалою оцінювання) -1 бал, оскільки переважна більшість дерев мають високо підняті крони у зв'язку з високою густотою насаджень, тобто $1 / 3$ частина дерев не покрита листками. Галявини та поляни монотонні та невеликі. Середній показник естетичності парку - 1,8 балів. Варто згадати, що з двох боків парк оточений річкою Дніпро, що справляє великий позитивний естетичний вплив.

Отже загалом парк «Наталка» має непогані естетичні властивості, територія благоустроєна, доглянута, наявні пішохідні та велосипедні доріжки, достатня кількість місць для сидіння, присутні об’єкти спортивного призначення. Більшість дерев мають прийнятні декоративні властивості.

Висновки. Провівши екологічну оцінку дендрофлори паркової екосистеми «Наталка», що знаходиться в урбанізованому середовищі міста Києва з'ясували, що видовий склад дендрофлори парку представлений 9 родинами, 13 видами. Серед представників є види едифікатори (30\%) та інтродуценти (23\%). Більшість видів парку $є$ геліофітами, мезофітами, оліготрофами та характеризуються високою 60 
морозостійкістю. Дендрофлора парку має 1 категорію стану із загальним індексом 90,8\%, тобто характеризується високими життєвими показниками, а деревостій характеризується як здоровий. Естетична оцінка парку $-83,1 \%$. В цілому паркова екосистема має бал - 1,8, тобто $\epsilon$ необхідність проведення додаткових заходів з покращення декоративності та естетичного сприйняття.

\section{Література:}

1. Агальцова В.А. Основы лесопаркового хозяйства : учебнометодическое пособие. Москва: МГТУ им. Н.Э. Баумана, 2007. 40 с.

2. Алексеев В.А. Диагностика жизненного состояния деревьев и древостоев. Москва, 1989. № 4. С. 51-57.

3. Боголюбов А.С., Панков А.Б. Простейшая методика геоботанического описания леса: Методическое пособие для педагогов дополнительного образования и учителей. М: Экосистема, 1996. 17 с.

4. Кофман Г.Б. Рост и форма деревьев. Новосибирск: Наука, 1986. $264 \mathrm{c}$.

5. Кучерявий В.П. Озеленення населених місць: Підручник для студ. вищих навч. закладів. Львів: Світ, 2005. 456 с.

6. Лукьянец А.Г. О методическом подходе к оценке типов парковых насаждений. Лесной вестник. 2010. № 1. С. 21-25.

7. Неверова О.А. Древесные растения и урбанизированная среда: Экологические и биотехнологические аспекты. Новосибирск: Наука, 2003. $222 \mathrm{c}$.

8. Поплавская Г.И. Экология растений. Москва: Сов. наука, $1948.312 \mathrm{c}$.

9. Пятницкий С.С. Курс дендрологи. Харьков: Изд-во ХГУ, $1960.420 \mathrm{c}$.

10. Цыганов Д.Н. Экоморфы флоры хвойно-широколиственных лесов. Москва: Сов. наука, 1976. 60 с. 